\title{
PEMBELAJARAN BIOLOGI MODEL POE (PREDICTION, OBSERVATION, EXPLANATION) MELALUI LABORATORIUM RIIL DAN LABORATORIUM VIRTUIL DITINJAU DARI AKTIVITAS BELAJAR DAN KEMAMPUAN BERPIKIR ABSTRAK
}

\author{
Sawitri Epi Wahyuni ${ }^{1}$, Suciati Sudarisman ${ }^{2}$ Puguh Karyanto $^{3}$ \\ ${ }^{1}$ Program Studi Pendidikan Sains, Pascasarjana Universitas Sebelas Maret Surakarta \\ Surakarta, 57126, Indonesia \\ sawitri.epi@gmail.com \\ ${ }^{2}$ Program Studi Pendidikan Sains, Pascasarjana Universitas Sebelas Maret Surakarta \\ Surakarta, 57126, Indonesia \\ suciati_sudarisman@yahoo.com \\ ${ }^{3}$ Program Studi Pendidikan Sains, Pascasarjana Universitas Sebelas Maret Surakarta \\ Surakarta, 57126, Indonesia \\ karyarina@yahoo.com
}

\begin{abstract}
Abstrak
Tujuan penelitian ini untuk mengetahui pengaruh pembelajaran model POE melalui laboratorium riil dan laboratorium virtuil ditinjau dari aktivitas belajar dan kemampuan berpikir abstrak terhadap hasil belajar. Penelitian ini menggunakan metode eksperimen dengan desain faktorial $2 \times 2 \times 2$. Populasi penelitian adalah seluruh siswa kelas VIII SMP Negeri 1 Plupuh Sragen. Sampel penelitian ditentukan secara acak dengan teknik cluster random sampling terdiri dari dua kelas. Kelas eksperimen I diberi perlakuan menggunakan laboratorium riil terdiri dari 32 siswa dan kelas eksperimen II diberi perlakuan menggunakan laboratorium virtuil terdiri dari 32 siswa. Pengumpulan data menggunakan teknik tes untuk data hasil belajar kognitif, psikomotor dan kemampuan berpikir abstrak, angket untuk data aktivitas dan hasil belajar afektif, lembar observasi untuk data psikomotor dan afektif. Uji hipotesis penelitian menggunakan anava tiga jalan sel tak sama dengan bantuan software SPSS 17. Hasil penelitian didapatkan bahwa: (1) hasil belajar pembelajaran POE melalui laboratorium riil lebih tinggi daripada laboratorium virtuil, baik aspek kognitif, psikomotor, maupun afektif; (2) siswa dengan aktivitas belajar tinggi memiliki hasil belajar yang lebih baik daripada siswa dengan aktivitas belajar rendah; (3) siswa dengan kemampuan berpikir abstrak tinggi memiliki hasil belajar yang lebih baik daripada siswa dengan kemampuan berpikir abstrak rendah; (4) terdapat interaksi antara pembelajaran model POE melalui laboratorium riil dan laboratorium virtuil dengan aktivitas belajar terhadap hasil belajar; (5) tidak terdapat interaksi antara pembelajaran model POE melalui laboratorium riil dan laboratorium virtuil dengan kemampuan berpikir abstrak terhadap hasil belajar; (6) terdapat interaksi antara aktivitas belajar dan kemampuan berpikir abstrak terhadap hasil belajar; (7) tidak terdapat interaksi antara pembelajaran model POE melalui laboratorium riil dan laboratorium virtuil, aktivitas belajar, dan kemampuan berpikir abstrak terhadap hasil belajar.
\end{abstract}

Kata kunci: Model POE, Laboratorium Riil, Laboratorium Virtuil, Aktivitas Belajar, Kemampuan Berpikir Abstrak

\section{Pendahuluan}

Salah satu upaya memacu kualitas pendidikan. Aplikasi pendidikan di sekolah diwujudkan dalam proses pembelajaran yang mampu memberdayakan segala potensi siswa untuk membangun pengetahuan sendiri dengan dibantu oleh guru sebagai fasilitator. Pembelajaran Ilmu Pengetahuan Alam (IPA) bertujuan untuk membantu siswa agar mampu menguasai pengetahuan tentang keteraturan sains. Pengetahuan tersebut diperoleh melalui proses ilmiah sehingga siswa memiliki sikap ilmiah yang dapat digunakan untuk memecahkan masalah dalam kehidupan seharihari.

Carin and Sund (dalam Wenno, 2008:3) menyebutkan bahwa hakikat IPA meliputi scientific product, scientific processes, dan scientific attitudes. Produk IPA yang meliputi fakta, konsep, prinsip diperoleh melalui serangkaian proses penemuan ilmiah dengan metode ilmiah dan didasari oleh sikap ilmiah. IPA diajarkan dengan cara berproses, berbasis aktivitas nyata melalui cara mengajar yang 
berorientasi pada proses ilmiah. Serangkaian proses pada pembelajaran IPA biologi di sekolah dapat memberikan suatu pengalaman nyata bagi siswa. Hal ini relevan dengan filosofi belajar menurut teori konstruktivisme bahwa siswa dapat mengkonstruksi pengetahuannya sendiri melalui pengalaman nyata sehingga menjadi lebih bermakna (Baharudin dan Esa, 2008:116).

Hakikat IPA memberikan implikasi terhadap proses pembelajaran biologi di kelas. Berbagai permasalahan belajar yang dihadapi siswa dipahami oleh guru guna memberikan solusi untuk mengatasinya. Pada dasarnya siswa sudah memiliki pengetahuan yang harus dikembangkan oleh guru dengan berbagai metode. Pengajaran IPA dirancang sedemikian rupa sehingga dapat menyediakan berbagai pengalaman belajar. Apabila siswa mengalami hal-hal yang dipelajari, serta mampu mengaitkan antara materi yang dipelajari dengan kehidupan nyata atau belajar secara alamiah, dapat menjadikan belajar lebih bermanfaat dan bermakna (Ausubel dalam Dahar, 1989:111).

Materi biologi khususnya materi pencernaan merupakan materi yang cukup sulit untuk dipelajari. Meskipun materi ini nyata tetapi peristiwa yang terjadi tidak dapat terlihat secara langsung seperti proses pencernaan makanan di rongga perut sehingga sulit untuk dipahami. Materi biologi tersebut akan lebih terlihat konkret dan mudah dipahami oleh siswa apabila dalam pembelajaran dilengkapi dengan media. Media pembelajaran merupakan segala sesuatu yang dapat digunakan oleh guru dalam membantu dan mempermudah berinteraksi dalam proses pembelajaran untuk mencapai tujuan belajar. Media dapat membantu guru dalam menyampaikan informasi, umpan balik dan respon yang positif dari siswa, menambah motivasi belajar dan meningkatkan perhatian serta konsentrasi terhadap proses pembelajaran.

Kondisi pembelajaran IPA di SMP Negeri 1 Plupuh saat ini guru belum sepenuhnya melaksanakan pembelajaran IPA sebagaimana hakikatnya. Kondisi ini disebabkan karena masih lemahnya pengetahuan dan wawasan guru tentang hakikat IPA. Materi pelajaran cenderung diajarkan secara verbal tekstual dan kurang berproses ilmiah. Kegiatan pembelajaran belum memberikan kesempatan siswa untuk mengembangkan kemampuan mengamati dan memprediksi terhadap suatu fenomena alam. Banyak siswa memiliki nilai di bawah kriteria ketuntasan minimal (KKM) yang ditetapkan sekolah yaitu 70 .

Hasil belajar dipengaruhi faktor eksternal dan internal siswa. Faktor internal seperti aktivitas belajar dan kemampuan berpikir abstrak tiap-tiap siswa bervariasi. Aktivitas belajar merupakan seluruh kegiatan siswa dalam proses belajar, baik kegiatan fisik maupun kegiatan psikis. Pengajaran yang efektif memberikan kesempatan pada siswa untuk belajar sendiri ataupun melakukan aktivitas sendiri. Kemampuan berpikir abstrak atau kemampuan berpikir imajinatif merupakan kemampuan memikirkan hal, kejadian atau peristiwa yang belum terjadi. Siswa mampu membuat prediksi, membuat kesimpulan yang tepat dan memecahkan masalah tanpa harus berhadapan langsung dengan benda-benda, kejadian atau peristiwa nyata sehingga dapat menghasilkan hasil belajar yang baik. Berdasarkan pandangan di atas, untuk memperbaiki hasil belajar maka faktor internal siswa perlu diperhatikan.

Inovasi pembelajaran merupakan upaya untuk mengatasi kesenjangan antara harapan dengan kenyataan. Inovasi pembelajaran dilakukan dengan menerapkan dan mengembangkan berbagai model, metode, dan strategi mengajar yang sesuai dengan hakikat IPA. Model pembelajaran POE (prediction, observation, explanation) merupakan salah satu model pembelajaran yang dikembangkan untuk menemukan kemampuan siswa dalam memprediksi suatu fenomena alam serta alasan mereka dalam membuat prediksi tersebut. Model pembelajaran ini lebih difokuskan dalam menemukan gejala yang diprediksi, diobservasi, dan dijelaskan kesesuaian antara prediksi dengan hasil observasi (Suparno, 2007: 102). Model POE memiliki beberapa metode saintifik yang merupakan bagian dari pembelajaran IPA, yaitu membuat hipotesis (predict), melakukan pengamatan (observe), dan menganalisis (explain).

Kehadiran media dalam pembelajaran sains khususnya biologi memiliki peran yang sangat penting. Materi biologi yang sulit ditunjukkan secara nyata, bersifat abstrak, berukuran mikroskopis, dan sulit disampaikan dengan kata-kata akan menjadi mudah 
disampaikan dan menarik bagi siswa. Penggunaan media untuk mendapatkan pengalaman langsung dapat dilakukan menggunakan obyek sebenarnya, atau penggunaan alat-alat praktikum dalam kegiatan laboratorium riil. Pengalaman belajar juga dapat diperoleh dengan memanfaatkan media berupa obyek tiruan yang menyerupai benda aslinya, misalnya menggunakan alat peraga, gambar, video dan simulasi komputer melalui laboratorium virtuil.

Laboratorium riil memungkinkan siswa menggunakan alat-alat laboratorium yang tersedia di sekolah untuk melakukan serangkaian kegiatan percobaan sehingga siswa dapat mengalami secara langsung setiap tahap percobaan. Laboratorium virtuil menggunakan program komputer untuk mensimulasikan serangkaian percobaan tanpa melakukan kegiatan langsung. Siswa mengamati dan mempelajari setiap tahap percobaan melalui monitor komputer.

Berdasarkan uraian di atas, penerapan pembelajaran dengan model POE dengan laboratorium riil dan laboratorium virtuil diharapkan dapat mengatasi masalah pembelajaran khususnya dalam upaya meningkatkan hasil belajar siswa di SMP Negeri 1 Plupuh Sragen.

Tujuan penelitian ini untuk mengetahui: (1) perbedaan hasil belajar antara pembelajaran model POE melalui laboratorium riil dan laboratorium virtuil; (2) perbedaan hasil belajar antara siswa yang memiliki aktivitas belajar tinggi dan rendah; (3) perbedaan hasil belajar antara siswa yang memiliki kemampuan berpikir abstrak tinggi dan rendah; (4) antara pembelajaran model POE melalui laboratorium riil dan laboratorium virtuil dengan aktivitas belajar terhadap hasil belajar; (5) interaksi antara pembelajaran model POE melalui laboratorium riil dan laboratorium virtuil dengan kemampuan berpikir abstrak terhadap hasil belajar; (6) interaksi antara aktivitas belajar dan kemampuan berpikir abstrak terhadap hasil belajar; (7) interaksi antara pembelajaran model POE melalui laboratorium riil dan laboratorium virtuil, aktivitas belajar, dan kemampuan berpikir abstrak terhadap hasil belajar.

\section{Metode Penelitian}

Penelitian ini menggunakan metode eksperimen dengan desain faktorial $2 \times 2 \times 2$. Populasi penelitian adalah seluruh siswa kelas VIII SMP Negeri 1 Plupuh Sragen. Sampel penelitian ditentukan secara acak dengan teknik cluster random sampling terdiri dari dua kelas. Kelas eksperimen I diberi perlakuan menggunakan laboratorium riil terdiri dari 32 siswa dan kelas eksperimen II diberi perlakuan menggunakan laboratorium virtuil terdiri dari 32 siswa.

Pengumpulan data menggunakan teknik tes untuk data hasil belajar kognitif, psikomotor, dan kemampuan berpikir abstrak, angket untuk data aktivitas dan hasil belajar afektif, lembar observasi untuk data psikomotor dan afektif. Instrumen sebelum digunakan diujicobakan terlebih dahulu untuk mengetahui kelayakannya meliputi uji validitas menggunakan korelasi Product Moment, uji reliabilitas menggunakan rumus KuderRichardson, uji daya beda dan uji taraf kesukaran. Uji prasyarat analisis meliputi uji normalitas menggunakan Shapiro-Wilk Test dan uji homogenitas menggunakan Levene Test dengan bantuan software SPSS 17. Uji hipotesis penelitian menggunakan anava tiga jalan desain faktorial $2 \times 2 \times 2$ isi sel tidak sama pada taraf signifikasi $\alpha=0,05$ dengan bantuan software SPSS 17.

\section{Hasil Penelitian dan Pembahasan}

\section{Data Hasil Belajar Siswa}

Tabel 1. Data Hasil Belajar Lab. Riil dan Lab, Virtuil.

\begin{tabular}{|c|c|c|c|c|}
\hline & $\begin{array}{c}\text { Jumlah } \\
\text { Data }\end{array}$ & Kognitif & Afektif & Psikomotor \\
\hline Lab. Riil & 32 & 76,9 & 76,0 & 77,0 \\
\hline Lab. Virtuil & 32 & 75,1 & 74,2 & 75,0 \\
\hline $\begin{array}{l}\text { Aktivitas } \\
\text { Tinggi }\end{array}$ & 35 & 79,2 & 77,6 & 78,5 \\
\hline $\begin{array}{l}\text { Aktivitas } \\
\text { Rendah }\end{array}$ & 29 & 72,2 & 72,1 & 72,9 \\
\hline Abstrak Tinggi & 33 & 79,8 & 78,4 & 79,0 \\
\hline Abstrak Rendah & 31 & 71,9 & 71,5 & 72,7 \\
\hline
\end{tabular}

Berdasarkan Tabel 1 terlihat bahwa rerata hasil belajar pembelajaran model POE melalui laboratorium riil menghasilkan hasil belajar lebih baik daripada melalui laboratorium virtuil pada aspek kognitif, afektif, dan psikomotor. 
Rerata hasil belajar siswa dengan aktivitas belajar tinggi menghasilkan hasil belajar lebih baik daripada siswa dengan aktivitas belajar rendah pada aspek kognitif, afektif, dan psikomotor.Rerata hasil belajar siswa dengan kemampuan berpikir abstrak tinggi menghasilkan hasil belajar lebih baik daripada siswa kemampuan berpikir abstrak rendah pada aspek kognitif, afektif, dan psikomotor.

\section{Data Aktivitas Belajar}

Tabel 2. Data Aktivitas Belajar Lab. Riil dan Lab, Virtuil.

\begin{tabular}{lcc}
\hline & Jumlah Data & Rerata \\
\hline Lab. Riil & 32 & 111,7 \\
\hline Lab. Virtui & 32 & 109,1 \\
\hline
\end{tabular}

Berdasarkan Tabel 2 terlihat bahwa rerata aktivitas belajar pembelajaran model POE pada kelas laboratorium riil lebih tinggi daripada laboratorium virtuil.

\section{Data Kemampuan Berpikir Abstrak}

Tabel 3. Data Kemampuan Berpikir Abstrak Lab. Riil dan Lab, Virtuil.

\begin{tabular}{lcc}
\hline & Jumlah Data & Rerata \\
\hline Lab. Riil & 32 & 17,8 \\
\hline Lab. Virtuil & 32 & 22,8 \\
\hline
\end{tabular}

$\begin{gathered}\text { Berdasarkan Tabel } 3 \text { terlihat bahwa } \\ \text { kemampuan berpikir abstrak }\end{gathered}$
rerata pembelajaran model POE pada kelas laboratorium virtuil lebih tinggi daripada melalui laboratorium riil.

\section{Pengujian Hipotesis}

Pengujian hipotesis dengan analisis varian (anava) tiga jalan desain faktorial $2 \times 2 \times$ 2 isi sel tidak sama pada taraf signifikasi $\alpha=$ 0,05 menggunakan bantuan software SPSS 17 . Keputusan uji jika sig.> 0,05 maka Ho diterima, jika sig. $<0,05$ maka Ho ditolak.

Tabel 4. Hasil Uji Anava

\begin{tabular}{|l|l|l|l|l|}
\hline \multirow{2}{*}{ Hip. } & \multirow{2}{*}{ Uji Anava } & Kog. & Afek. & Psiko. \\
\hline 1 & Media & 0,019 & 0,002 & 0,012 \\
\hline 2 & Aktivitas belajar & 0,000 & 0,000 & 0,002 \\
\hline 3 & Kemampuan abstrak & 0,000 & 0,000 & 0,000 \\
\hline 4 & $\begin{array}{l}\text { Media*Aktivitas } \\
\text { belajar }\end{array}$ & 0,045 & 0,043 & 0,243 \\
\hline 5 & $\begin{array}{l}\text { Media*Kemampuan } \\
\text { abstrak }\end{array}$ & 0,147 & 0,201 & 0,995 \\
\hline 6 & Aktivitas belajar & 0,003 & 0,898 & 0,020 \\
\hline
\end{tabular}

\begin{tabular}{|l|l|l|l|l|}
\hline & $\begin{array}{l}\text { *Kemampuan } \\
\text { abstrak }\end{array}$ & & & \\
\hline 7 & $\begin{array}{l}\text { Media*Aktivitas } \\
\text { belajar*Kemampuan } \\
\text { abstrak }\end{array}$ & 0,218 & 0,644 & 0,143 \\
\hline
\end{tabular}

Uji Lanjut Anava

Tabel 5. Hasil Uji Lanjut

\begin{tabular}{|c|c|c|c|c|}
\hline \multirow{2}{*}{ Hip } & \multirow{2}{*}{ Uji Lanjut } & \multicolumn{3}{|c|}{ Sig. } \\
\hline & & Kog. & Afek. & Psik. \\
\hline 1 & Lab riil dan virtuil & 0,24 & 0,127 & 0,154 \\
\hline 2 & Aktivitas tinggi dan rendah & 0,00 & 0,000 & 0,000 \\
\hline 3 & $\begin{array}{l}\text { Kemampuan abstrak tinggi dan } \\
\text { rendah }\end{array}$ & 0,00 & 0,000 & 0,000 \\
\hline \multirow[t]{4}{*}{4} & $\begin{array}{l}\text { Lab riil aktivitas tinggi dan lab } \\
\text { riil aktivitas rendah }\end{array}$ & 0,00 & 0,000 & - \\
\hline & $\begin{array}{l}\text { Lab riil aktivitas tinggi dan lab } \\
\text { virtuil aktivitas tinggi }\end{array}$ & 0,70 & 0,292 & - \\
\hline & $\begin{array}{l}\text { Lab riil aktivitas rendah dan lab } \\
\text { virtuil aktivitas rendah }\end{array}$ & 0,81 & 0,890 & - \\
\hline & $\begin{array}{l}\text { Lab virtuil aktivitas tinggi dan } \\
\text { lab virtuil aktivitas rendah }\end{array}$ & 0,00 & 0,005 & - \\
\hline \multirow[t]{4}{*}{6} & $\begin{array}{l}\text { Aktivitas tinggi kemampuan } \\
\text { abstrak tinggi dan aktivitas tinggi } \\
\text { kemampuan abstrak rendah }\end{array}$ & 0,00 & - & 0,000 \\
\hline & $\begin{array}{l}\text { Aktivitas tinggi kemampuan } \\
\text { abstrak tinggi dan aktivitas } \\
\text { rendah kemampuan abstrak tinggi }\end{array}$ & 0,00 & - & 0,000 \\
\hline & $\begin{array}{lrr}\text { Aktivitas } & \text { tinggi } & \text { kemampuan } \\
\text { abstrak } & \text { rendah dan } & \text { aktivitas } \\
\text { rendah } & \text { kemampuan } & \text { abstrak } \\
\text { rendah } & & \end{array}$ & 0,07 & - & 0,138 \\
\hline & $\begin{array}{lrr}\text { Aktivitas } & \text { rendah } & \text { kemampuan } \\
\text { abstrak tinggi dan } & \text { aktivitas } \\
\text { rendah } & \text { kemampuan } & \text { abstrak } \\
\text { rendah } & & \\
\end{array}$ & 0,01 & - & 0,039 \\
\hline
\end{tabular}

Nilai sig. > 0,05 keputusan Ho diterima, menunjukkan ada perbedaan yang tidak signifikan rerata uji. Nilai sig. $<0,05$ keputusan Ho ditolak, menunjukkan ada perbedaan yang signifikan rerata uji.

\section{Pembahasan}

1. Pengaruh pembelajaran biologi dengan model POE melalui laboratorium riil dan laboratorium virtuil terhadap hasil belajar.

Berdasarkan hasil uji anava diperoleh bahwa ada perbedaan pembelajaran POE melalui laboratorium riil dan laboratorium virtuil terhadap hasil belajar kognitif, afektif dan psikomotor. Rerata hasil pembelajaran POE melalui laboratorium riil adalah 76,9 (kognitif), 76,0 (afektif) dan 77,0 (psikomotor) sedangkan laboratorium virtuil 75,1 (kognitif), 74,2 (afektif) dan 75,0 (psikomotor). Berdasarkan 
hasil perhitungan uji lanjut anava diketahui bahwa penerapan model POE melalui laboratorium riil dan laboratorium virtuil memiliki pengaruh yang berbeda terhadap hasil belajar tetapi tidak signifikan.

Data menunjukkan bahwa rerata hasil belajar pembelajaran POE melalui laboratorium riil lebih tinggi daripada laboratorium virtual baik pada aspek kognitif, afektif, maupun psikomotor. Materi sistem pencernaan merupakan materi yang cukup sulit sehingga siswa akan lebih mudah memahami konsep apabila dalam pembelajaran dilengkapi dengan media. Penggunaan alat-alat laboratorium secara nyata dalam laboratorium riil mampu menanamkan konsep lebih dalam pada diri siswa sehingga diperoleh hasil belajar yang lebih baik daripada melalui laboratorium virtuil.

Hasil di atas sesuai dengan teori Piaget tentang perkembangan kognitif anak. Menurut Piaget (dalam Suparno, 2005: 25), siswa pada tingkat SMP berada pada masa transisi dari tahap operasional konkrit menuju ke arah operasional formal. Kehadiran objek nyata dalam pembelajaran dapat menciptakan makna dari apa yang dipelajari dengan semua potensi yang dimiliki siswa sehingga siswa lebih mudah memahami konsep materi pencernaan yang bersifat abstrak.

Pembelajaran menggunakan model POE baik melalui laboratorium riil dan laboratorium virtuil melatih siswa membuktikan hasil prediksinya melalui observasi secara langsung. Berdasarkan bukti-bukti yang didapat, siswa akan menemukan dan mengkonstruksi pengetahuannya sendiri. Hal ini relevan dengan teori belajar Bruner tentang belajar penemuan. Siswa berusaha sendiri mencari pemecahan masalah untuk menghasilkan pengetahuan yang bermakna.

Kegiatan observasi akan mempermudah siswa dalam memahami konsep karena siswa mengalami sendiri pengalaman belajar. Hal ini relevan dengan teori belajar Ausubel tentang belajar bermakna. Belajar bermakna menurut Ausubel (dalam Dahar, 1989: 112) merupakan suatu proses mengaitkan informasi baru dengan konsep-konsep relevan yang terjadi dalam struktur kognitif seseorang. Proses dalam belajar bermakna berkaitan dengan asimilasi informasi baru pada pengetahuan yang telah dimiliki siswa.
Latihan dan pengalaman dalam belajar dapat menghasilkan perubahan perilaku dalam diri siswa. Seperti halnya pendapat yang dikemukakan oleh Gagne bahwa belajar merupakan kegiatan yang kompleks, hasil belajar berupa kapabilitas, setelah belajar seseorang memiliki keterampilan, pengetahuan, sikap, dan nilai. Peningkatan kemampuan psikomotor dalam diri siswa yang diperoleh dalam pembelajaran akan berpengaruh pada prestasi afektif siswa. Hal ini terlihat pada prestasi afektif siswa yang meningkat seiring dengan peningkatan prestasi psikomotor siswa.

2. Pengaruh antara aktivitas belajar tinggi dan rendah terhadap hasil belajar.

Berdasarkan hasil uji anava diperoleh bahwa ada perbedaan aktivitas belajar tinggi dan rendah terhadap hasil belajar kognitif, afektif dan psikomotor. Rerata hasil belajar siswa dengan aktivitas belajar tinggi adalah 79,2 (kognitif), 77,6 (afektif) dan 78,5 (psikomotor) sedangkan aktivitas belajar rendah adalah 72,2 (kognitif), 72,1 (afektif) dan 72,9 (psikomotor). Berdasarkan hasil perhitungan uji lanjut anava diketahui bahwa ada perbedaan yang signifikan antara siswa dengan aktivitas belajar tinggi dan rendah terhadap hasil belajar kognitif, afektif dan psikomotor. Siswa dengan aktivitas belajar tinggi memiliki hasil belajar yang lebih baik daripada siswa dengan aktivitas belajar rendah.

Data penelitian menunjukkan rerata nilai siswa dengan aktivitas belajar tinggi lebih baik daripada siswa dengan aktivitas belajar rendah baik pada aspek kognitif, afektif maupun psikomotor. Hal ini menunjukkan bahwa siswa yang memiliki aktivitas tinggi mempunyai kesempatan yang lebih besar untuk lebih mendalami materi, memiliki keterampilan proses yang berdampak pada perilaku dan sikap siswa, sehingga pada akhirnya diperoleh hasil belajar yang lebih baik daripada siswa dengan aktivitas belajar rendah.

Piaget (dalam Sardiman, 2007:100) menerangkan bahwa anak berpikir sepanjang ia berbuat. Oleh karena itu, agar anak berpikir maka anak harus diberi kesempatan untuk berbuat sendiri. Aktivitas dalam hal ini meliputi aktivitas fisik dan mental. Siswa terlibat aktif dalam setiap kegiatan pembelajaran seperti melihat, mendengarkan, menulis, tetapi harus didukung pula oleh aktivitas mental seperti 
menanggapi, mengingat, menganalisis dan mengambil keputusan, sehingga terbentuk keserasian antara aktivitas fisik dan aktivitas mental yang berdampak terhadap keoptimalan belajar siswa.

Aktivitas siswa lebih terlihat pada pembelajaran diskusi kelompok yang dapat merekonstruksi pengetahuan siswa. Pengetahuan yang telah dimiliki siswa sebelumnya dari pengalaman sehari-hari dapat direkonstruksi setelah mengalami proses belajar melalui interaksi dengan siswa, guru maupun berbagai sumber belajar lain di sekolah. Hal ini sesuai dengn teori Vygotsky yang menitikberatkan pada interaksi antara individu dengan lingkungan sosialnya. Vygotsky berpendapat bahwa anak-anak menyerap percakapan orang-orang lain dan kemudian menggunakan percakapan itu untuk membantu diri sendiri memecahkan masalah (Slavin, 2008: 60). Rancangan pembelajaran melalui kerja kelompok memungkinkan terjadinya kerja sama diantara siswa dengan tingkat kemampuan berbeda-beda. Siswa dapat bekerja sama untuk saling membantu belajar yang akan berdampak pada peningkatan pemahaman konsep, pengembangan kemampuan psikomotor dan perubahan perilaku afektif siswa.

3. Pengaruh antara kemampuan berpikir abstrak tinggi dan rendah terhadap hasil belajar.

Berdasarkan hasil uji anava diperoleh bahwa ada perbedaan kemampuan berpikir abstrak tinggi dan rendah terhadap hasil belajar kognitif, afektif dan psikomotor. Rerata hasil belajar siswa dengan kemampuan berpikir abstrak tinggi adalah 79,8 (kognitif), 78,4 (afektif) dan 79,0 (psikomotor) sedangkan kemampuan berpikir abstrak rendah adalah 71,9 (kognitif), 71,5 (afektif) dan 72,7 (psikomotor). Berdasarkan hasil perhitungan uji lanjut anava diketahui bahwa ada perbedaan yang signifikan antara siswa dengan kemampuan berpikir abstrak tinggi dan rendah terhadap hasil belajar kognitif, afektif dan psikomotor. Siswa dengan kemampuan berpikir abstrak tinggi memiliki hasil belajar yang lebih baik daripada siswa dengan kemampuan berpikir abstrak rendah.

Materi pencernaan merupakan materi yang bersifat abstrak, objek yang dipelajari dan peristiwa yang terjadi tidak dapat terlihat secara langsung sehingga siswa membutuhkan kemampuan berimajinasi untuk dapat memahami konsep tentang pencernaan. Siswa harus mampu memikirkan kejadian atau peristiwa yang belum terjadi dan memperkirakan bentuk objek maupun peristiwa yang akan terjadi dalam imajinasi atau khayalan.

Teori tentang perkembangan kognitif pada masa transisi dari tahap operasional konkrit menuju ke arah operasional formal yang ditandai dengan kemampuan siswa untuk berpikir abstrak. Siswa dapat berpikir logis dan dapat mengambil kesimpulan lepas dari apa yang dapat diamati pada saat itu. Pemikirannya dapat melampaui waktu dan tempat, tidak hanya terikat pada hal yang sudah diamati. Siswa menyusun, membangun pengetahuan lama yang semula tidak sesuai kemudian dibandingkan dan kemudian disesuaikan dengan pengetahuan baru, sehingga terbentuklah pengetahuan baru (Sagala, 2008: 24).

Siswa dengan kemampuan berpikir abstrak tinggi memiliki hasil belajar kognitif yang lebih baik daripada siswa dengan kemampuan berpikir abstrak rendah. Hal ini dapat dijelaskan bahwa siswa yang memiliki kemampuan berpikir abstrak yang tinggi akan lebih mudah mengkonkretkan materi-materi yang bersifat abstrak dalam imajinasi mereka sehingga siswa akan lebih mudah pula memahami konsep mereka pelajari. Siswa dapat berpikir fleksibel dan efektif, serta mampu menghadapi persoalan-persoalan yang kompleks.

4. Pengaruh interaksi antara pembelajaran model POE melalui laboratorium riil dan laboratorium virtuil dengan aktivitas belajar terhadap hasil belajar.

Berdasarkan hasil uji anava diperoleh bahwa nilai sig. $<0,05$ (kognitif dan afektif) yang berarti ada interaksi antara pembelajaran melalui laboratorium riil dan virtuil dengan aktivitas belajar terhadap hasil belajar kognitif dan afektif. Sementara itu untuk hasil belajar psikomotor nilai sig. > 0,05 yang berarti tidak ada interaksi antara pembelajaran melalui laboratorium riil dan virtuil dengan aktivitas belajar terhadap hasil belajar psikomotor.

Hasil uji lanjut menunjukkan bahwa terdapat pengaruh berbeda yang diberikan oleh pembelajaran melalui laboratorium riil dan virtuil terhadap hasil belajar pada variasi 
aktivitas belajar tinggi dan rendah. Pembelajaran melalui laboratorium riil pada siswa dengan aktivitas belajar tinggi memberikan kontribusi yang paling besar terhadap hasil belajar yaitu dengan rerata 79,4 (kognitif) dan 78,1 (afektif). Sementara itu pembelajaran melalui laboratorium riil pada siswa dengan aktivitas belajar rendah memberikan hasil belajar yang paling rendah yaitu 71,9 (kognitif) dan 72,0 (afektif). Hasil belajar yang lebih baik diperoleh siswa dengan aktivitas belajar rendah apabila diberi pembelajaran melalui laboratorium virtuil yaitu dengan rerata 72,3 (kognitif) dan 72,2 (afektif).

Berdasarkan perbandingan rerata tersebut dapat dikemukakan bahwa siswa dengan aktivitas belajar tinggi menghasilkan hasil belajar yang paling baik jika diberi pembelajaran melalui laboratorium riil. Sementara itu siswa dengan aktivitas belajar rendah menghasilkan hasil belajar yang lebih baik jika diberi pembelajaran melalui laboratorium virtuil.

Hasil uji lanjut menunjukkan bahwa siswa dengan aktivitas belajar tinggi menghasilkan hasil belajar yang paling baik jika diberi pembelajaran melalui laboratorium riil. Hal tersebut dapat dipahami karena dalam kegiatan pembelajaran harus melibatkan siswa baik secara fisik, intelektual maupun secara emosional sehingga benar-benar berpartisipasi aktif melakukan kegiatan belajar. Pembelajaran melalui laboratorium riil memberikan kesempatan kepada siswa untuk menggunakan berbagai sumber belajar yang tersedia di laboratorium baik berupa benda nyata maupun benda tiruan. Kondisi tersebut menjadikan siswa yang memiliki aktivitas tinggi lebih leluasa untuk mengeksplorasi sumber belajar secara langsung sehingga mendapatkan pengalaman belajar yang nyata.

Berdasarkan hasil uji lanjut diperoleh bahwa siswa dengan aktivitas belajar rendah menghasilkan hasil belajar yang lebih baik jika diberi pembelajaran melalui laboratorium virtuil. Hal ini dapat dijelaskan karena siswa yang memiliki aktivitas belajar rendah memiliki kecenderungan tidak banyak melakukan aktivitas fisik atau motoriknya. Meskipun siswa memiliki aktivitas fisik yang rendah namun siswa mampu mengembangkan aktivitas mental secara aktif misalnya dengan menyimak atau menganalisis suatu bahan pelajaran dalam pikirannya. Karakteristik siswa yang demikian akan lebih tepat apabila disajikan bahan pelajaran yang bersifat visual misalnya dengan pembelajaran melalui laboratorium virtuil. Meskipun siswa memiliki aktivitas belajar rendah namun mampu memberikan hasil belajar yang lebih baik.

5. Pengaruh interaksi antara pembelajaran model POE melalui laboratorium riil dan laboratorium virtuil dengan kemampuan berpikir abstrak terhadap hasil belajar.

Hasil uji anava menunjukkan bahwa nilai sig. > 0,05 pada ketiga aspek hasil belajar kognitif, afektif dan psikomotor. Hal ini berarti bahwa tidak ada interaksi antara pembelajaran melalui laboratorium riil dan virtuil dengan kemampuan berpikir abstrak terhadap hasil belajar kognitif, afektif, dan psikomotor.

Tidak adanya interaksi tersebut terlihat dari rerata hasil belajar pembelajaran melalui laboratorium riil maupun laboratorium virtuil apabila diterapkan pada siswa dengan kemampuan berpikir abstrak tinggi cenderung lebih tinggi jika dibandingkan dengan siswa dengan kemampuan berpikir abstrak rendah. Demikian pula rerata hasil belajar siswa baik dengan kemampuan abstrak tinggi maupun rendah apabila diberi pembelajaran melalui laboratorium riil cenderung menghasilkan rerata yang lebih tinggi dibandingkan melalui laboratorium virtuil.

Menurut Piaget (dalam Rahyubi, 2012:134) pada tahap operasional formal seorang remaja sudah mulai mengerti cara berpikir abstrak. Siswa yang memiliki kemampuan abstrak tinggi dalam menyelesaikan suatu permasalahan tidak hanya melalui penyelesaian secara konkrit dengan melihat langsung hasilnya, tetapi siswa tersebut mampu berpikir terlebih dahulu secara teoritis.

Monks, Knoers dan Siti Rahayu (2002:223) menjelaskan cara siswa pada tahap operasional formal dalam menyelesaikan masalah. Anak yang berpikir operasional formal akan bekerja dengan memikirkan dulu secara teoritis, menyelesaikan masalahnya dengan penyelesaian berbagai hipotesis yang mungkin ada. Siswa yang memiliki kemampuan abstrak tinggi pada proses pembelajaran baik melalui laboratorium riil maupun laboratorium virtuil memiliki kemampuan menganalisis suatu permasalahan dibandingkan dengan siswa yang 
memiliki kemampuan abstrak rendah. Melalui analisis tersebut siswa dapat membuat strategi untuk menyelesaikan suatu permasalahan tentang materi pelajaran yang sedang dipelajari.

Siswa dengan kemampuan berpikir abstrak tinggi mempunyai kelebihan dalam menemukan berbagai kombinasi alternatif penyelesaian masalah. Apabila siswa tersebut mampu menyelesaikan masalah secara tepat, maka ia mampu mengkonstruksi pengetahuan sendiri dan memiliki tingkah laku problem solving yang ilmiah, serta menghasilkan hasil belajar yang lebih baik.

6. Pengaruh interaksi antara aktivitas belajar dengan kemampuan berpikir abstrak terhadap hasil belajar

Berdasarkan hasil uji anava diperoleh bahwa nilai sig. < 0,05 (kognitif dan psikomotor) yang berarti ada interaksi aktivitas belajar denga kemampuan berpikir abstrak terhadap hasil belajar kognitif dan psikomotor. Sementara itu untuk hasil belajar afektif nilai sig. > 0,05 yang berarti tidak ada interaksi antara aktivitas belajar dan kemampuan berpikir abstrak terhadap hasil belajar afektif.

Siswa dengan aktivitas belajar tinggi dan kemampuan abstrak tinggi memberikan kontribusi yang paling besar terhadap hasil belajar yaitu dengan rerata 82,29 (kognitif) dan 81,3 (psikomotor). Sementara itu siswa dengan aktivitas belajar rendah dan kemampuan abstrak rendah memberikan hasil belajar yang paling rendah yaitu 71,1 (kognitif) dan 72,1 (psikomotor).

Berdasarkan hasil uji lanjut diperoleh bahwa hasil belajar siswa dengan aktivitas belajar tinggi dan kemampuan berpikir abstrak rendah memiliki beda rerata yang tidak signifikan dengan siswa dengan aktivitas rendah dan kemampuan berpikir abstrak rendah, yaitu dengan nilai sig. 0,079>0,05 (kognitif) dan $0,138>0,05$ (psikomotor). Siswa dengan aktivitas belajar tinggi dan kemampuan berpikir abstrak rendah memiliki rerata 73,8 (kognitif) dan 74,0 (psikomotor), sedangkan siswa dengan aktivitas rendah dan kemampuan berpikir abstrak rendah memiliki rerata 71,1 (kognitif) dan 72,1 (psikomotor). Dengan demikian aktivitas belajar baik tinggi maupun rendah akan memberikan hasil belajar yang sama baiknya pada siswa yang memiliki kemampuan berpikir abstrak rendah.
Siswa yang memiliki aktivitas belajar tinggi dan kemampuan abstrak tinggi memberikan kontribusi yang paling besar terhadap hasil belajar karena dalam proses pembelajaran siswa harus melibatkan kemampuan fisik, mental, emosional dan intelektualnya. Melalui aktivitas belajar yang tinggi, memungkinkan siswa untuk mencoba dan melakukan sesuatu dalam memperoleh informasi dan pemecahan masalah. Siswa dapat terlibat secara aktif dalam proses pembelajaran, misalnya melakukan pengamatan obyek dengan panca indera, mengajukan pertanyaan, mengemukakan pendapat, mencatat, menggunakan alat, melakukan percobaan dan sebagainya.

Melalui aktivitas belajar yang tinggi siswa dapat terlibat secara langsung dan mengalami sendiri proses pembelajaran. Keterlibatan siswa tersebut menjadikan siswa memperoleh pengalaman belajar langsung dan nyata, sehingga pengetahuan yang diperoleh siswa menjadi lebih bermakna. Menurut Ausubel (dalam Dahar, 1989: 112), belajar bermakna merupakan suatu proses mengaitkan informasi baru dengan konsep-konsep relevan yang terjadi dalam struktur kognitif seseorang. Siswa memahami bagaimana upaya yang harus dilakukan untuk membuktikan sebuah prediksi jawaban permasalahan yang ia ajukan. Kemampuan hipotetik ini berkembang dari kemampuan berpikir abstrak yang dimiliki siswa. Dengan demikian, aktivitas belajar yang tinggi dan ditunjang dengan kemampuan berpikir abstrak tinggi dapat menghasilkan hasil belajar yang tinggi pula.

Berdasarkan uji lanjut diperoleh bahwa aktivitas belajar baik tinggi maupun rendah akan memberikan hasil belajar yang sama baiknya pada siswa yang memiliki kemampuan berpikir abstrak rendah. Setiap siswa memiliki tahap perkembangan mental yang berbeda, sehingga kemampuan akomodasi siswa juga berbeda. Kondisi tersebut sesuai dengan hasil penelitian bahwa aktivitas belajar tinggi dan kemampuan berpikir abstrak rendah memiliki hasil belajar yang berbeda tidak signifikan dengan siswa aktivitas belajar rendah dan kemampuan berpikir abstrak rendah. Kemampuan berpikir abstrak rendah tersebut menjadikan siswa mengalami hambatan dalam mencapai struktur mental yang stabil, sehingga meskipun siswa memiliki aktivitas belajar 
tinggi namun memiliki hasil belajar yang sama baiknya dengan siswa aktivitas belajar rendah.

7. Pengaruh interaksi antara pembelajaran model POE melalui laboratorium riil dan laboratorium virtuil, aktivitas belajar, dan kemampuan berpikir abstrak terhadap hasil belajar

Hasil uji anava menunjukkan bahwa nilai sig. > 0,05 pada ketiga aspek hasil belajar kognitif, afektif dan psikomotor. Dengan demikian diperoleh bahwa tidak ada interaksi antara pembelajaran POE melalui laboratorium riil dan virtual, aktivitas belajar dan kemampuan berpikir abstrak terhadap hasil belajar kognitif, afektif dan psikomotor. Terdapat kecenderungan bahwa pembelajaran melalui laboratorum riil maupun virtuil pada siswa dengan aktivitas belajar dan kemampuan berpikir abstrak tinggi menghasilkan rerata hasil belajar yang lebih baik daripada siswa dengan aktivitas belajar dan kemampuan berpikir abstrak rendah.

Menurut Wartono (2004: 10), siswa dapat mengembangkan keterampilan proses, keterampilan memecahkan masalah, serta merasakan fenomena alam melalui kegiatan laboratorium. Pembelajaran melalui laboratorium riil memberikan kesempatan kepada siswa berinteraksi langsung dengan obyek yang dipelajari, baik obyek nyata maupun obyek tiruan yang menyerupai aslinya. Proses belajar demikian memungkinkan siswa memperoleh pengalaman belajar langsung dari aktivitas yang ia lakukan sendiri. Sementara itu pembelajaran melalui laboratorium virtuil meskipun siswa tidak dihadapkan pada obyek yang nyata namun menyerupai aslinya atau merupakan simulasi dari peristiwa yang sebenarnya. Penggunaan laboratorium mampu mengurangi verbalisme dan kesalahan pemahaman konsep tentang suatu materi pelajaran.

Siswa dengan aktivitas belajar tinggi dan kemampuan berpikir abstrak tinggi memiliki kesempatan yang lebih leluasa mengeksplorasi, memanfaatkan dan berinteraksi langsung dengan berbagai sumber belajar untuk memperoleh pegetahuan baru. Aktivitas siswa juga terlihat pada pembelajaran yang melibatkan kelompok belajar, terutama dalam kegiatan diskusi.
Demikian pula siswa dengan kemampuan abstrak tinggi mampu menyusun serangkaian penalaran hipotesis, mulai berpikir dan berargumnetasi mengenai hal-hal yang abstrak. Siswa mampu mengambil kesimpulan tanpa harus berhadapan langsung dengan benda konkritnya tatapi cukup dengan penalaran yang terjadi dalam struktur kognitifnya melalui simbol-simbol, ide-ide maupun abstraksi. Pemikiran deduktif hipotesis memungkinkan siswa menarik kesimpulan dari asumsi-asumsi yang masih bersifat hipotesis.

\section{Kesimpulan dan Rekomendasi}

\section{Kesimpulan}

Berdasarkan analisis dan pembahasan hasil penelitian, dapat dibuat kesimpulan sebagai berikut: (1) hasil belajar pembelajaran POE melalui laboratorium riil lebih tinggi daripada laboratorium virtuil, baik aspek kognitif, psikomotor, maupun afektif; (2) siswa dengan aktivitas belajar tinggi memiliki hasil belajar yang lebih baik daripada siswa dengan aktivitas belajar rendah; (3) siswa dengan kemampuan berpikir abstrak tinggi memiliki hasil belajar yang lebih baik daripada siswa dengan kemampuan berpikir abstrak rendah; (4) terdapat interaksi antara pembelajaran model POE melalui laboratorium riil dan laboratorium virtuil dengan aktivitas belajar terhadap hasil belajar kognitif dan afektif; (5) tidak terdapat interaksi antara pembelajaran model POE melalui laboratorium riil dan laboratorium virtuil dengan kemampuan berpikir abstrak terhadap hasil belajar; (6) terdapat interaksi antara aktivitas belajar dan kemampuan berpikir abstrak terhadap hasil belajar kognitif dan psikomotor; (7) tidak terdapat interaksi antara pembelajaran model POE melalui laboratorium riil dan laboratorium virtuil, aktivitas belajar, dan kemampuan berpikir abstrak terhadap hasil belajar

\section{Rekomendasi}

Pembelajaran menggunakan model POE melalui laboratorum riil maupun virtuil dapat dijadikan alternatif model pembelajaran pada materi sistem pencernaan karena dapat meningkatkan hasil belajar pada aspek kognitif, 
afektif, dan psikomotor. Di dalam pelaksanaan pembelajaran di sekolah, guru diharapkan memperhatikan karakteristik materi yang diajarkan agar dapat menerapkan model dan media pembelajaran yang sesuai sehingga didapatkan hasil belajar yang maksimal. Guru harus lebih aktif dalam penggunaan media yang ada pada laboratorium riil dan lebih kreatif dalam membuat atau memodifikasi media melalui laboratorum virtuil. Agar penerapan model POE berjalan lancar, guru disarankan untuk dapat lebih mengelola waktu dengan baik.

\section{Daftar Pustaka}

Baharudin, Esa Bur Wahyuni. (2008). Teori Belajar dan Pembelajaran. Yogyakarta: Ar-ruzz Media Group.

Dahar, Ratna Wilis. (1989). Teori-teori Belajar. Jakarta: Erlangga.

Monks, Knoers \& Haditono, Siti Rahayu. (2002). Psikologi Perkembangan. Yogyakarta: UGM Press.

Rahyubi, Heri. (2012). Teori-teori Belajar dan Aplikasi Pembelajaran Motorik. Majalengka. Referens

Sagala, Syaiful. (2008). Konsep dan Makna Pembelajaran. Bandung: Alfa Beta.

Sardiman. A.M. (2007). Interaksi dan Motivasi Belajar Mengajar. Jakarta: Raja Grafindo Persada

Slavin, Robert E. (2008). Psikologi Pendidikan, Teori dan Praktek. Bandung: Indeks.

Suparno, Paul. (2005). Teori Perkembangan Kognitif Jean Piaget. Yogyakarta: Kanisius

Fisikararan
Menyenangkan.
Universitas Sanata Darma.

Wartono dkk. (2004). Materi Pelatihan Terintegrasi Sains. Jakarta: Depdiknas.
Wenno I. H. (2008). Strategi Belajar Mengajar Sains Berbasis Kontekstual. Yogyakarta: Inti Media. 